\title{
Psychometric Studies of the Learning Strategies Scale for University Students ${ }^{1}$
}

\author{
Evely Boruchovitch ${ }^{2}$ \\ Universidade Estadual de Campinas, \\ Campinas-SP, Brazil
}

\author{
Acácia Aparecida Angeli dos Santos \\ Universidade São Francisco, \\ Itatiba-SP, Brazil
}

\begin{abstract}
The aim of this article is to examine the psychometric properties of a learning strategies scale for university students. The scale was composed of 49 Likert scale items related to cognitive and metacognitive strategies. It was applied in a sample of 1,490 university students. The factor analysis revealed that 35 items had acceptable loadings and identified a three factor structure: Factor 1 - Cognitive and Metacognitive Self-regulation, Factor 2 - Internal Resource and Context regulation, and Factor 3 - Social regulation. Its internal consistency was assessed by Cronbach's alpha and was .87 for the total scale, .86 for Factor 1, .71 for Factor 2 and .65 for Factor 3. The total variance explained was $26.6 \%$. Further studies are suggested based on confirmatory factor analyses, so that the scale can be better utilized in psychoeducational evaluation.
\end{abstract}

Keywords: metacognition, test validity, higher education

\section{Estudos Psicométricos da Escala de Estratégias de Aprendizagem Para Estudantes Universitários (EEA-U)}

Resumo: O presente trabalho tem como objetivo examinar as propriedades psicométricas de uma escala de estratégias de aprendizagem para alunos universitários. A escala contém 49 itens fechados, em forma de escala Likert, relacionados às estratégias cognitivas e metacognitivas. Foi aplicada a uma amostra de 1490 estudantes do Ensino Superior. A análise fatorial da escala revelou que 35 itens apresentaram cargas fatoriais aceitáveis e uma estrutura de três fatores: Fator 1 - Autorregulação Cognitiva e Metacognitiva, Fator 2 - Autorregulação dos Recursos Internos e Contextuais e Fator 3 - Autorregulação Social. Os índices de consistência interna, aferidos pelo alpha de Cronbach, foram, respectivamente, 0,87 para a escala total, 0,86 para o Fator 1, 0,71 para o 2 e 0,65 para o 3. A variância total explicada foi de $26,6 \%$. Recomenda-se a continuidade de estudos de validade e precisão, com base na análise fatorial confirmatória para o seu melhor aproveitamento em avaliação psicoeducacional.

Palavras-chave: metacognição, validade do teste, ensino superior

\section{Estudios Psicométricos de la Escala de Estrategias de Aprendizaje Para Estudiantes Universitarios}

\begin{abstract}
Resumen: Este estudio tuvo como objetivo examinar las propiedades psicométricas de una escala de estrategias de aprendizaje para estudiantes universitarios. La escala contiene 49 ítems cerrados, en forma de escala Likert, relacionados a las estrategias cognitivas y metacognitivas. Se aplicó a una muestra de 1.490 estudiantes de Educación Superior. El análisis factorial reveló que 35 ítems tuvieron cargas factoriales aceptables y una estructura de tres factores: Factor 1 - Autorregulación Cognitiva y Metacognitiva, Factor 2 - Autorregulación de Recursos Internos y Contextuales y Factor 3 - Autorregulación Social. Los índices de consistencia interna, medidos por el alfa de Cronbach, fueron, respectivamente, .87 para la escala total, .86 para el Factor 1, .71 para el 2 y .65 para el 3. La varianza total explicada fue de $26,6 \%$. Se recomienda la continuidad de estudios de validez y fiabilidad, basados en análisis factorial confirmatorio para su mejor aprovechamiento en evaluación psicoeducacional.
\end{abstract}

Palabras clave: metacognición; validación de test; educación superior

Researchers dedicated to the study of learning strategies recognize the important role these strategies play in students' selfregulatory processes, as well as that they are a strong protective factor for school and academic success. Self-regulated learning is currently advocated as the desirable type of learning, as it requires

\footnotetext{
1 Support: This research was sponsored by the National Council for Scientific and Technological Development - CNPq (Protocol no. 302464/2010-7)

2 Correspondence address:

Evely Boruchovitch. Faculdade de Educação da Universidade Estadual de Campinas. Avenida Bertrand Russell, 801. Barão Geraldo. Caixa Postal 6120. Campinas-SP, Brazil. E-mail: evely@unicamp.br
}

students to take responsibility for their learning process. Due to its complexity, it involves metacognition, motivation, control of attention and emotions, and the use of learning strategies by students (Azevedo et al., 2012; Boruchovitch \& Santos, 2006; Clayton, Blumberg, \& Auld, 2010; Dembo \& Seli, 2012; Karpicke, Butler, \& Roediger, 2009; Weinstein, Acee, \& Jung, 2012; Zimmerman \& Schunk, 2011). Specialists have embraced the challenge of identifying factors that promote quality of learning. In this sense, learning strategies, among other variables, have been the subject of several investigations, since their use helps greatly in overcoming the personal and environmental difficulties of students, in the different education segments 
(Dembo \& Seli, 2012; Oliveira, Boruchovitch, \& Santos, 2011; Tinajero, Lemos, Araújo, Ferraces, \& Páramo, 2012; Wang, Kim, Bong, \& Ahn, 2013; Weinstein et al., 2012).

As described by Boruchovitch and Santos (2006), learning strategies are defined in the literature as sequences of procedures or activities that are chosen for the purpose of facilitating the acquisition, storage and/or use of information (Nisbet \& Schucksmith, 1986). Weinstein and Mayer (1985) identified five types of strategies: rehearsal strategies, elaboration strategies, organizational strategies, comprehension monitoring strategies, and affective strategies. Rehearsal strategies involve active repetition, both in speech and in writing, of what has been learning. Elaboration strategies require the use of connections between the material to be learned and old and familiar material (paraphrasing, summarizing, creating analogies, elaborating, and answering questions about the learned material). The organizational strategies are related to the structuring of the material to be learned, dividing it and relating its parts (topics, hierarchies, network concepts, and of diagrams). Comprehension monitoring strategies involve the constant awareness regarding how much of the content is assimilated and of immediate actions to overcome difficulties. Affective strategies are related to awareness and control of the impact of affective factors on learning (motivation, anxiety), aiming to maintain an internal state that favors good information processing. Self-assessment, organization and transformation, establishment of goal and planning, seeking information, registration of information, self-monitoring, environmental organization, seeking help, and revision are strategies that have also been identified in other studies (Zimmerman \& Martinez-Pons, 1986).

Some theorists classify learning strategies into two major groups: cognitive and metacognitive. According to Dembo and Seli (2012), cognitive strategies refer to a set of behaviors that influence the learning process so that information can be stored more efficiently, while metacognitive strategies are procedures used by the individual to plan, monitor and regulate their own thinking. There are also specialists, such as McKeachie, Pintrich, Lin, Smith and Sharma (1990), who additionally divide the learning strategies into three broad categories - cognitive, metacognitive and resource management - subdividing the cognitive strategies into simple and complex tasks. This type of distinction is not made for the metacognitive and resource management strategies.

As identified by Boruchovitch and Santos (2006), it is evident that the diversity in the nomenclature of learning strategies is more terminological than semantic. Learning strategies more specifically named by some authors, in reality can be grouped into the broad categories proposed by others, such as the two major groups: cognitive and metacognitive strategies, which seem to encompass a wide range of strategies. According to Weinstein et al. (2012), it is difficult to define learning strategies, since this term has not been used in a standardized way by specialists of the subject (Duncan \& McKeachie, 2005; Dunn, Lo, Mulvenon, \& Sutcliffe, 2012; Zimmerman \& Martinez-Pons, 1986). However, these authors highlight that there is consensus among researchers that learning strategies involve the use of cognition and metacognition, and involve motivation, emotion, and student engagement in behaviors that increase the likelihood of obtaining success in learning. They also consider that currently it is more frequent to use expressions such as self-regulated learning strategies, or to think of them as a set of procedures that enable and strengthen the self-regulated learning.

Differences related to the terminology have had an impact on the comprehension of the construct itself and, in a certain way, reflect the difficulty in its measurement, as stated by Boruchovitch and Santos (2006). Among the instruments available in the international literature for evaluating learning strategies, the main ones can be highlighted as: the Learning and Study Strategies Inventory (LASSI), developed by Weinstein, Zimmerman and Palmer (1988), the Motivated Strategies for Learning Questionnaire (MSLQ) of Pintrich and De Groot (1989), and the Self-Regulated Learning Interview Schedule of Zimmerman and Martinez-Pons (1986).

\section{Existing Learning Strategy Assessment Scales: A Brief Description}

The Motivated Strategies for Learning Questionnaire (MSQL) consists of 81 Likert-type items, divided into two scales: Motivation and Learning Strategies which, in turn, are subdivided into several subscales (Duncan \& McKeachie, 2005; Pintrich \& De Groot, 1989). With regard to learning strategies, the focus of this study, the scale is divided into two main subscales: Learning Strategies (rehearsal, elaboration, organization, critical thinking, and metacognitive self-regulation) and Time Management and Study Environment (regulation of effort, time, learning by interacting with peers, and asking for help). Recent studies have re-examined the factorial structure of this scale, indicating the need for the inclusion of two new scales: General Learning Strategies and Clarification Strategies (Dunn et al., 2012).

The LASSI is an inventory originally constructed for university students with 76 statements, organized into the following 10 Likert-type subscales: Attitude, Motivation, Time Management, Anxiety, Concentration, Information Processing, Selecting Main Ideas, Study Aids, Self-testing, and Test Strategies, aiming to evaluate different components of strategic learning.

The LASSI-HS is another version of the LASSI, which is also composed of 10 subscales, and was adapted for students of high school, junior high, and the higher grades of elementary education (Weinstein \& Palmer, 1990). In the Portuguese adaptation, performed by Figueira (1994), its items were reduced to 50 and separated into only two major factors. The first was designated as Facilitative Study and Learning Conditions, which included the original subscales Time Management, Concentration, Motivation, Anxiety, and Attitude, and the second factor was called Specific Study and Learning Strategies, which grouped the initial subscales 
of Self-testing, Test Strategies, Study Aids, Selecting Main Ideas, and Information Processing.

In Brazil, studies on learning strategies began in the 1990s, with the use of instruments translated and adapted from the international literature having predominance (Cardoso \& Bzuneck, 2004; Costa \& Boruchovitch, 2004). However, there has been a growth in initiatives directed toward the construction of instruments to measure these strategies in various education segments. The emergence of a cognitive and metacognitive strategies scale (Santos \& Boruchovitch, 2001, 2008; Santos, Boruchovitch, Primi, Bueno, \& Zenorini, 2004) and a motivation and learning strategies inventory (Machado, Bzuneck, \& Guimarães 2004), both for university students, may be cited as examples. Furthermore, the university student version of the LASSI, was also translated, adapted and validated for Brazilian students of São Paulo and Paraná by Bartalo (2006). Of the 10 subscales of the original instrument, the author found support for eight, with the Self-testing and Test Strategies subscales being excluded and the emergence of one new subscale: Concerns when Studying.

From the psychometric perspective, the results of national and international studies show, on the one hand, good internal consistency for the scales, but on the other, reveal the configuration of different groupings of items, which appear either as isolated factors, or combined or renamed (Bartalo, 2006; Duncan \& McKeachie, 2005; Dunn et al., 2012; Figueira, 1994; Machado et al., 2005; Santos et al., 2004). Undoubtedly, this inconsistency in results reinforces the need for further studies aimed at improving the items or revising the definition of the construct.

The recognized importance of learning strategies at all levels of schooling, together with the studies which highlight its deficient use, even in Higher Education (Bembenutty, 2011; Berger \& Karabenick, 2011; Brophy, 2010; Erdamar, 2011; Marini \& Boruchovitch, 2014; Pattal, Awad, \& Cestone, 2014), and the lack of national instruments thatenablea fasterassessment of the repertoire of learning strategies led the authors of the present study to develop a scale for university students (Santos \& Boruchovitch, 2001, 2008; Santos et al., 2004). Accordingly, this article aims to both describe the steps of constructing the Learning Strategies Scale of Santos and Boruchovitch (2001, 2008) and present the results of recent psychometric studies obtained with this instrument. It is hoped that these findings will contribute to improve the psychoeducational assessment in Higher Education. A brief history of the construction of the scale and a description of the methodology used in the present study will be presented next.

\section{Method}

\section{Participants}

The sample consisted of 1,490 students from public and private universities of different Brazilian cities, 76 (5.1\%) from Londrina, 125 (8.4\%) from Jundiaí,
110 (7.4\%) from Campinas, 136 (9.1\%) from Itatiba, 48 (3.2\%) from Mato Grosso, 45 (3.0\%) from Joinville, 294 (19.7\%) from Uberlândia, 562 (37.7\%) from Rio de Janeiro, and $94(6.3 \%)$ from Goiás. Participants were of both genders, with 703 (47.2\%) being male and 787 (52.8\%) female, and attended various semesters (first to tenth) of courses of Pedagogy $(n=807 ; 54.2 \%)$, Visual Arts $(n=7 ; 0.5 \%)$, Mathematics $(n=1 ; 0.07 \%)$, Music $(n=1 ; 0.07 \%)$, Philosophy $(n=11 ; 0.7 \%)$, Physics $(n=$ $10 ; 0.7 \%)$, History $(n=34 ; 2.3 \%)$, Social Sciences $(n=$ $2 ; 0.13 \%)$, Life Sciences $(n=9 ; 0.6 \%)$, Psychology $(n=$ $46 ; 3.1 \%)$ and the Naval Higher Education Course $(n=$ $562 ; 37.7 \%)$. The ages of the participants were grouped into four ranges: below 20 years $(n=191 ; 15.6 \%), 20$ to 29 years $(n=859 ; 70.0 \%), 30$ to 39 years $(n=112 ; 9.1 \%)$, and over 40 years $(n=65 ; 5.3 \%)$. Of the total participants, $263(17.6 \%)$ did not report their age.

\section{Instruments}

Learning Strategies Assessment Scale for University Students and a synthesis of its initial studies (EEA-U). Initially, 28 items were drafted in the form of a Likert-type scale with four alternative answers: always, sometimes, rarely, and never. The items aimed to evaluate what makes the university student study and learn. They were constructed based on the literature of the area, so that the instrument included rehearsal, elaboration and organization types of cognitive strategies and metacognitive strategies related to the planning, monitoring and regulation of learning (Dembo \& Seli, 2012; Pintrich \& De Groot, 1989; Weinstein \& Mayer, 1985; Zimmerman \& Martinez-Pons, 1986).

After the drafting of the items, the contents of each was evaluated and classified as cognitive, metacognitive, or not applicable by the authors and two independent judges who were experts on the subject. The evaluation of the judges also contributed to the revision of some items that had ambiguous wording. The percentage of concordance achieved among the judges and authors ranged from $85 \%$ to $100 \%$. The following are some examples of the questions of the scale: "Do you repeat information orally while reading the text?", "Do you identify how much or how little you are learning?" ( ) always ( ) sometimes ( ) rarely ( ) never. The always response scores 4 points, sometimes 3 , rarely 2 , and never 1 point. The maximum number of points that can be obtained on the scale is 112 , with the minimum being 28 . The higher the score of the student, the greater the tendency toward strategic behavior. The scale is also accompanied by a set of simple instructions in order to standardize its application. A pilot study was conducted with a small group of university students, who detected no need to review some items, and then the scale was applied in initial studies with university students (Santos et al., 2004).

Primarily, this version of the scale was used in the study of Santos et al. (2004) and applied with 434 university students of both genders and from varied courses of a private university 
in the state of São Paulo. Exploratory factor analysis, principal component analysis and varimax rotation, identified a structure of five factors, which explained $44 \%$ of the variance and were named as follows: Simple Cognitive Strategies (Factor 1), Metacognitive Strategies (Factor 2), Metacognitive Regulation Strategies (Factor 3), Complex Cognitive Strategies (Factor 4) and Affective Support Strategies (Factor 5). It was observed that the items were not grouped in a way entirely consistent with the literature. Furthermore, although the total scale and Factors 1 and 2 achieved satisfactory values of internal consistency, the other three factors presented low alpha values. Further details regarding the psychometric problems of this initial version of the scale can be found in the study by Santos et al. (2004).

Thus, considering the importance of obtaining a valid and reliable measure of learning strategies for university students, the refinement of the initial version of the scale was initiated (Santos \& Boruchovitch, 2008). For this, a further 21 items were constructed and tested at this point. The aim was to construct items that would strengthen all the cognitive and metacognitive strategy categories. Regarding the metacognitive strategies, new items encompassed both behaviors that revealed the presence of good strategies and those that showed their absence. The four answer choices in Likert scale format from the previous version were maintained (always, sometimes, rarely, never), the score of which can range from 49 to 196 points. In this new composition of the scale, 19 items were related to cognitive strategies, 23 to metacognitive strategies, and 7 were of the dysfunctional metacognitive type, the latter group having its score inverted. Thus, the original design of the scale was maintained, in which the higher the score of the student, the higher their propensity to use favorable strategies for their learning.

The new items were evaluated and classified by postgraduate judges and experts in learning strategies, yielding a percentage of concordance above $80 \%$, among them and the authors of the scale. Content analysis of the items allowed them to initially be grouped into three general subscales: Cognitive Strategies, Metacognitive Strategies, and Absence of Dysfunctional Metacognitive Strategies. The following are examples of items of the scale: "Do you write down in full the explanations of the teacher?" (Cognitive Strategies subscale), "Do you plan your study activities?" (Metacognitive Strategies subscale) and "Do you get distracted or think of something else when reading, studying or doing work?" (Absence of Dysfunctional Metacognitive Strategies subscale).

The second version of the scale with 49 items was applied with new samples in some studies with university students of Licenciate and Pedagogy courses prior to the examination of its factor structure, in which the items were grouped in the three previously mentioned subscales. Preliminary analysis with 158 university students revealed high internal consistency for the total scale, measured through Cronbach's alpha $(\alpha=.85)$, through the Guttman Split-half $(\alpha=.74)$ and through the Spearman Brown formula ( $\alpha=.74)$ (Boruchovitch \& Santos, 2011). Furthermore, significant positive correlations were found for the total score of the strategies scale and its subscales with intrinsic motivation and significant negative correlations with extrinsic motivation, as well as positive correlations with emotional regulation strategies among students of public and private universities of cities of São Paulo and the state of Minas Gerais. Further details can be found in recent works (Bortoletto \& Boruchovitch, 2013; Cunha \& Boruchovitch, 2012).

\section{Procedure}

Data collection. Data collection was carried out from 2009 to 2012 in five public and six private universities of nine Brazilian cities, applied by Undergraduate and Postgraduate students, specially trained for the task, after the clarification of the aims of the study to the students and the signature of the informed consent form, in duplicate, for those who agreed to participate in the study.

The application of the scale was carried out collectively, based on the standardized instructions that accompany it. Students were instructed on how to fill the scale and to raise their hand if they had any questions. It took approximately 15 to 20 minutes for the students to complete it.

Data analysis. As the results obtained in the first study with an earlier version of the scale were not congruent with the theoretically expected results from the international literature and the sample, at the time, had also not been sufficiently large and representative (Santos et al., 2004), a new exploratory factor analysis was conducted on the study sample. The data obtained were coded in spreadsheets. The Statistical Analysis System, version 8.02 software was used for the validity and reliability studies of the scale, to evaluate the indicators of adequacy of the corresponding matrix (KMO and Bartlett's test of sphericity), and for the performance of the factor analysis. Using the same program, the principal components analysis and the calculation of internal consistency (Cronbach's alpha) were carried out for the resulting components.

\section{Ethical Considerations}

The project was approved by the Research Ethics Committee of the Universidade São Francisco (Protocol no. 0151.0.142.000-09). All ethical guidelines recommended by the National Health Council (Resolution 196/96 and its complements, Ministry of Health) were followed.

\section{Results}

The Bartlett's test of sphericity indicated a correlation between the items $\left(X^{2}[1176, N=1,490]=17196.086\right.$; $p<.001)$. The measure of sample adequacy, ascertained through the Kaiser-Meyer-Olkin (KMO) index was .883. The data obtained through these two procedures showed that 
there was a very adequate probability level for the correlation between variables and that the sample was suitable for performing the Factor Analysis (Kline, 1994).

Thus, an exploratory factor analysis was conducted to examine the structure of the scale. Through the criterion of the selection of factors with an eigenvalue greater than one, 12 factors were obtained which explained $52.0 \%$ of the variability of the data. The scree plot test was used, as suggested by Cattell (1966), as a means of analyzing the number of factors to be maintained (Figure 1). Therefore, it was chosen to fix the extraction for three factors, explaining $26.6 \%$ of the total variability, since the curve stabilizes from this factor, without major increases in the cumulative percentage of explained variance.

To obtain the rotated matrix, the criterion of a minimum factor loading of 0.30 for the inclusion of items was stipulated (Kline, 1994). A three factor scale was obtained as a result of the principal component (PC) analysis. It was possible to name them as: Factor 1 Cognitive and Metacognitive Self-regulation Strategies, Factor 2 - Internal Resource and Context regulation Strategies, and Factor 3 - Social regulation Strategies. Factor 1, Cognitive and Metacognitive Self-regulation Strategies, was composed of 23 items $(1,2,3,4,5,6$, $7,8,9,10,12,13,14,15,20,24,25,27,29,30,31,34$, and 35) with saturation varying between .34 and .60 and eigenvalues of 8.09 , explaining $16.53 \%$ of the total variance. Factor 2, Internal and Contextual Resources regulation Strategies, consisted of 8 items $(11,17,18$, $19,21,22,23$, and 26) with saturation ranging between .34 and .60 and eigenvalues of 2.65 , explaining $5.42 \%$ of the total variance. Factor 3, Social regulation Strategies, was composed of four items $(16,28,32$, and 33) with saturation ranging between .34 and .60 and eigenvalues of 2.27 , explaining $3.46 \%$ of the total variance. The three

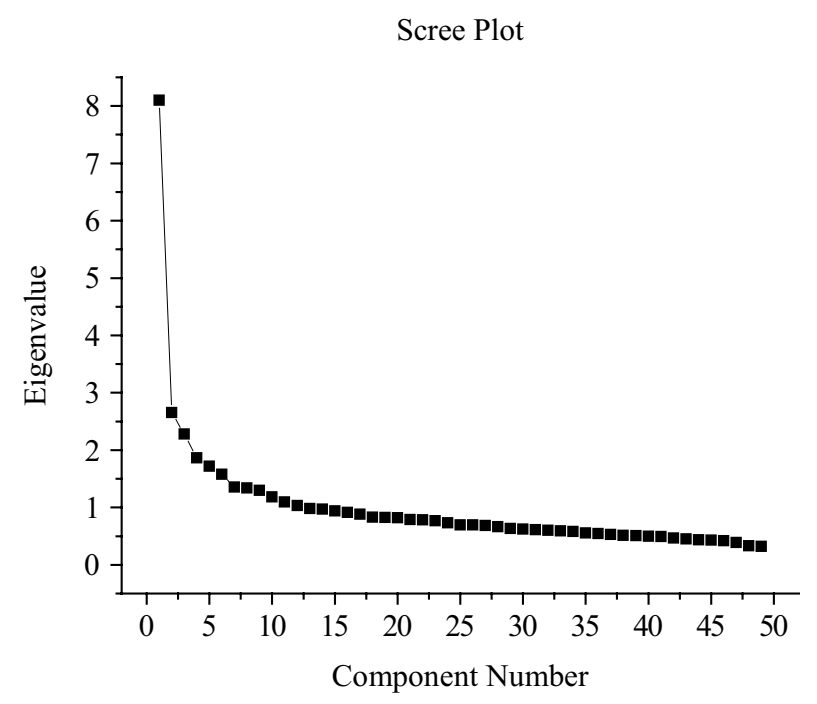

Figure 1. Scree plot of Items of the Evaluation of Learning Strategies Scale for University students. factors identified, although they reveal considerable consistency, from the theoretical perspective, allowed only $26.6 \%$ of the variability of the scale to be explained. With this being a less than desirable percentage $(<40 \%)$, it is suggested that further studies be carried out, aiming for a better comprehension of the construct in question.

For various reasons, 14 items were excluded. Of the original 49 items, nine did not achieve the minimum factor loading recommended in the literature (Kline, 1994). The following are examples of these items: "Do you stop during reading to see if you understand what has been read?" "Do you search the Internet?", "Do you study or work watching television?" and "Do you eat while studying or doing homework?". Five items loaded in factors that were unexpected according to the literature. As an illustration, the following items may mentioned as examples: "Do you memorize the content when you have a test?", which should have loaded in Factor 1 due to being a cognitive testing strategy, however its factor loading was concentrated in Factor 3. The same occurred with the item "Do you identify the main ideas and relate them through diagrams and conceptual maps?", which should have also loaded in Factor 1, since it is a organizational cognitive strategy, however, it actually loaded in Factor 3. The item "Do you motivate yourself for study activities?" should have loaded in Factor 2, however, was grouped in Factor 1.

Thus, the initially constructed scale with 49 items was replaced by a 35 -item scale after the principal components analysis. Table 1 presents the loadings of the final items in the factors after orthogonal Varimax rotation.

The number of factors identified through analyzing the Scree plot test coincided with the number of fixed factors. Therefore, it was decided to maintain the three factors, especially considering the theoretical coherence of the items and the sedimentation graph obtained from the analysis performed. Also, the correlation between Factors 1,2 and 3 was estimated by calculating Pearson's coefficient, finding weak or almost non-existent correlations, which were all without statistical significance. More precisely, $r=.23$ was obtained between Factors 1 and 2, $r=-.06$ between Factors 1 and 3 , and $r=.08$ between Factor 2 and 3. These three factors emerged very definitely in the EEA-U, with a relative independence between each other.

\section{Discussion}

This study found that the final 35 items of the EEA-U, when grouped in three factors, reveal a certain congruence of the scale with the theoretical constructs that it purports to measure. The main cognitive testing, development and organization strategies are grouped in Factor 1, as well as general metacognitive strategies related to planning, to monitoring of learning and to its regulation. This organization of cognitive and metacognitive strategies in a single factor is convergent with data from some studies (Duncan \& McKeachie, 2005; Weinstein et al., 1988), although not as a 
Table 1

Distribution of Items by Factor With Their Respective Factor Loadings

\begin{tabular}{llll}
\hline Items & F1 & F2 & F3 \\
\hline 1. Repeat information orally while reading the text & .37 & & \\
2. Write down in full the explanations of the teacher & .54 & \\
3. Identify your difficulties to learn certain & .37 & \\
topics or subjects & &
\end{tabular}

4. Summarize the texts indicated for study $\quad .40$

5. Read the texts indicated by the teacher $\quad .46$

6. Make notes in the text or on a separate sheet $\quad .53$

7. Write in your own words what you $\quad .55$ understood from the text

8. Read supplementary texts, in addition to $\quad .60$ those indicated by the teacher

9. Prepare questions and answers on the subject studied

10. Select the main ideas of the text

11. Control your anxiety in evaluation situations

12. Identify how much or how little you are learning

13. Request help from the teacher regarding doubts about the content

14. Review the notes taken in class

15. Search the dictionary for the meanings of unfamiliar words

16. Ask for help from colleagues in case of doubts

17. Manage your study time

18. Organize your study environment

19. Stay calm when faced with difficult tasks

20. Use other texts and books on the subject

21. Plan your study activities

22. Separate all the material needed for the task that you will perform

23. Manage to complete a task even when it is difficult or tedious

24. Check your mistakes after receiving the grade for a test

25. Try to redo questions that you got wrong in a test

26. Distract yourself or think of something else when reading, studying or doing work

27. Read your answers again before handing in a test

28. Study in a group

29. Note on the agenda things that you have to do

30. Make a schema on the paper (sketch, graph or drawing) to better understand the relationships between things

31. Paste reminders to remember what you need to do

32. Discuss the matter with colleagues to see whether you understood

33. Ask someone to go over the material

34 Reread the material to understand it better

35. Create questions about the subject you are studying and try to answer them separate factor. More precisely, this factor grouped strategies similar to the Information Processing, Selecting Main Ideas, and Test Strategies scales of the LASSI, and similar to the Learning Strategies subscale of the Pintrich and De Groot Scale (1989), re-examined by Duncan and McKeachie (2005). Factor 2 grouped the items related to the management of internal and external conditions that are facilitators of learning. This result is consistent with that obtained by Figueira (1994) with a Portuguese sample. The items are also similar in content to those found by Duncan and McKeachie (2005), again, not as an isolated factor, but as a subscale of the Learning Strategies Scale, which they called Time Management and Study Environment; this subscale also included items similar to those that emerged in Factor 3 of this study, such as learning through colleagues and asking for help from colleagues and teachers. Similarly, Factor 2 grouped items from the Motivation, Time Management, Anxiety, and Concentration scales of the LASSI (Weinstein et al., 1988), however, did not include those related to learning through interaction and social regulation that, in the LASSI, as in the present study, constituted a separate scale, called Study Aids. The data obtained here were also consistent in terms of content, with those of Bartalo (2006).

It should be mentioned that, while the items 'asking for help from colleagues' and 'learning through other social interactions' were organized in Factor 3, in the present study, the 'asking for help from teachers' item had its factor loading allocated in Factor 1. Considering the importance of asking for help as a self-regulation strategy, whether from teachers or significant others (Karabenick \& Dembo, 2011), it would be interesting if future studies sought to confirm whether asking for help from the teacher is actually seen differently by Brazilian students to asking for help from their colleagues.

Regarding reliability, the total scale and subscales achieved good internal consistency, measured by Cronbach's coefficient, producing the following alpha values: .87 for the total scale, .86 for Factor 1, .71 for Factor 2 and .65 for Factor 3 (Prieto \& Muñiz, 2000).

It can be said that the configuration of the EEA-U resembled more the two main factors 'Facilitatory or Inhibitory Conditions for Study' and 'Specific Learning Strategies for Study and Learning', found by Figueira (1994) in the validation of the HS version of the LASSI. Furthermore, the factors presented, as a set, more theoretical consistency and higher indices of internal consistency, when compared to the data obtained with the first version of the scale (Santos et al., 2004).

It is noteworthy that the EEA-U is an instrument that was specifically constructed for Brazilian students in Higher Education. With excellent psychometric qualities, the EEA-U was sensitive enough to assemble and map the key attributes indicated in the literature as characteristic of learning strategies, with a considerably smaller number of items (almost half), when compared to other existing instruments. Due to being less extensive, with 
easy application and rapid calculation, it could be very useful in the study, evaluation and diagnosis of learning strategies, one of the essential dimensions of strategic and self-regulated learning, according to several authors (Dembo \& Seli, 2012; Duncan \& McKeachie, 2005; Figueira, 1994; Pintrich \& De Groot, 1990; Weinstein et al., 2011; Zimmerman \& Martinez-Pons, 1996).

This study provides initial evidence of content and construct validity, and precision of a scale constructed for the evaluation of the learning strategies of Brazilian university students, which can be very useful for researchers, teachers and students. It is recommended, however, that future studies be directed toward overcoming the limitations of the present study. It is essential that further research be conducted with the current version of the scale so as to confirm its factor structure through confirmatory factor analysis procedures, which could also assess the adequacy of some items in which the factor loadings were lower in this study (.31 to .38). An analysis of the functioning of items through the item response theory (IRT) would also be valuable for better use of the scale for diagnosis and psychoeducational intervention.

It is also necessary to perform studies directed toward the evaluation of the temporal stability of the scale, and its relationship with important variables related to learning, such as measures of performance, self-efficacy, anxiety, and motivation, among others, so that evidence of other types of validity (concurrent, predictive, convergent and discriminant) can be estimated. Certainly, these correlational studies are promising, not only for a better understanding of other forms of validity of the EEA-U, but also to elucidate the relationships between learning strategies and these constructs which are highly relevant to the teaching-learning process.

It is expected that this study can contribute for a better understanding of Learning Strategies, in our context, by broadening the discussion of problems regarding their measurement and unveiling the complexity of an important dimension of self-regulated learning, particularly in a historical moment in which the educational context increasingly requires the students to have the ability to make quick, efficient and conscious decisions as well as to regulate their own learning process.

\section{References}

Azevedo, A. S., Dias, P. C., Salgado, A., Guimarães, T., Lima, I., \& Barbosa, A. (2012). Teacher-student relationship and self-regulated learning in Portuguese compulsory education. Paidéia (Ribeirão Preto), 22(52), 197-206. doi:10.1590/S0103-863X2012000200006

Bartalo, L. (2006). Mensuração de estratégias de estudo e aprendizagem de alunos universitários: Learning and study strategies inventory (LASSI) adaptação e validação para o Brasil (Unpublished doctoral dissertation). Universidade Estadual Paulista "Júlio de Mesquita Filho", Marília, SP.
Bembenutty, H. (2011). New directions for self-regulation of learning in postsecondary education. New Directions for Teaching and Learning, 126, 117-124. doi:10.1002/t1.450

Berger, J.-L., \& Karabenick, S. A. (2011). Motivation and students' use of learning strategies: Evidence of unidirectional effects in mathematics classrooms. Learning and Instruction, 21(3), 416-428. doi:10.1016/j.learninstruc.2010.06.002

Bortoletto, D., \& Boruchovitch, E. (2013). Learning strategies and emotional regulation of pedagogy students. Paidéia (Ribeirão Preto), 23(55), 235-242. doi:10.1590/1982-43272355201311

Boruchovitch, E., \& Santos, A. A. A. (2006). Estratégias de aprendizagem: Conceituação e avaliação. In A. P. P. Noronha, F. F. Sisto, \& A. A. A. Santos (Eds.), Facetas do fazer em avaliação psicológica (pp. 107-124). São Paulo, SP: Vetor.

Boruchovitch, E., \& Santos. A. A. A. (2011). Avaliação de estratégias cognitivas e metacognitivas na escolarização formal. Trabalho apresentado no Quinto Congresso Brasileiro de Avaliação Psicológica. Bento Gonçalves, RS. Abstract retrieved from http://www.ibapnet.org.br/congresso2011/ trabalhos/Avalia \% C $3 \%$ A $7 \%$ C $3 \%$ A 3 o \% 20 d e $\% 20$ es trat \% C $3 \%$ A 9 gi as $\% 20-\% 20$ Apresenta\%C3\%A 7\%C3\%A 30\%203\%20-\%20 Evely\%20Boruchovitch.pdf

Brophy, J. E. (2010). Motivating students to learn (3rd ed.). New York, NY: Routledge.

Cardoso, L. R., \& Bzuneck, J. A. (2004). Motivação no ensino superior: Metas de realização e estratégias de aprendizagem. Psicologia Escolar e Educacional, 8(2), 145-155. doi:10.1590/S1413-85572004000200003

Cattell, R. B. (1966). The scree test for the number of factors. Multivariate Behavioral Research, 1(2), 245-276. doi:10.1207/s15327906mbr0102_10

Costa, E. R., \& Boruchovitch, E. (2004). Compreendendo as relações entre estratégias de aprendizagem e ansiedade de alunos do ensino fundamental de Campinas. Psicologia: Reflexão e Crítica, 17(1), 15-24. doi:10.1590/S0102-79722004000100004

Clayton, K., Blumberg, F., \& Auld, D. P. (2010). The relationship between motivation, learning strategies and choice of environment whether traditional or including an online component. British Journal of Educational Technology, 41(3), 349-364. doi:10.1111/j.1467-8535.2009.00993.x

Cunha, N. B., \& Boruchovitch, E. (2012). Estratégias de aprendizagem e motivação para aprender na formação de professores. Interamerican Journal of Psychology, 46(2), 247-253.

Dembo, M. H., \& Seli, H. (2012). Motivation and learning strategies for college success: A focus on self-regulated learning. New York, NY: Routledge. 
Duncan, T. G., \& McKeachie, W. J. (2005). The making of the motivated strategies for learning questionnaire. Educational Psychologist, 40(2), 117-128. doi:10.1207/s15326985ep4002_6

Dunn, K. E., Lo, W.-J., Mulvenon, S. W., \& Sutcliffe, R. (2012). Revisiting the motivated strategies for learning questionnaire: A theoretical and statistical reevaluation of the metacognitive self-regulation and effort regulation subscales. Educational Psychological Measurement, 72(2), 312-331. doi:10.1177/0013164411413461

Erdamar, G. (2011). An investigation of student teachers' study strategies with respect to certain variables. Educational Research and Evaluation, 17(2), 69-83. doi:10.1080/13803611.2011.587607

Figueira, A. P. C. (1994). Inventário de estratégias de estudo e de aprendizagem - Learning and study strategies inventory - (LASSI) (Weinstein \& Palmer, 1990). Estudos de adaptação e validação. Psychologica, 12, 79-114.

Karabenick, S. A., \& Dembo, M. H. (2011). Understanding and facilitating self-regulated help seeking. New Directions for Teaching and Learning, 126, 33-43. doi:10.1002/tl.442

Karpicke, J. D., Butler, A. C., \& Roediger, H. L., III. (2009). Metacognitive strategies in student learning: Do students practice retrieval when they study on their own? Memory, 17(4), 471-479. doi:10.1080/09658210802647009

Kline, P. (1994). An easy guide to factor analysis. New York, NY: Routledge.

Machado, N., Bzuneck, J. A., \& Guimarães, S. E. R. (2004). Inventário de motivação e estratégias de aprendizagem. Unpublished manuscript.

Marini, J. A. S., \& Boruchovitch, E. (2014). Estratégias de aprendizagem de alunos brasileiros do ensino superior: Considerações sobre adaptação, sucesso acadêmico e aprendizagem autorregulada. E-PSI, 4(1), 102-126.

McKeachie, W. J., Pintrich, P. R., Lin, Y.-G., Smith, D. A. F., \& Sharma, R. (1990). Teaching and learning in the college classroom: A review of the research literature (2nd ed.). Ann Arbor, MI: University of Michigan Press/ National Center for Research to Improve Postsecondary Learning.

Ministério da Saúde. Conselho Nacional de Saúde. Resolução $N^{o} 196$, de 10 de outubro de 1996. Aprova as diretrizes e normas regulamentadoras de pesquisas envolvendo seres humanos. Retrieved from http://conselho.saude.gov.br/ resolucoes/reso_96.htm

Nisbet, J., \& Shucksmith, J. (1986). Learning Strategies. Londres. Routledge and Keagan Paul.

Oliveira, K. L., Boruchovitch, E., \& Santos, A. A. A. (2011). Estratégias de aprendizagem no ensino fundamental: Análise por gênero, série escolar e idade. Psico, 42(1), 98-105.
Pattal, E.A., Awad, G. H., \& Cestone, C. M. (2014). Academic potential beliefs and feelings: Conceptual development and relations with academics outcomes. Self and Identity, 13(1), 58-80. doi:10.1080/15298868.2012.738705

Pintrich, P. R., \& De Groot, E. V. (1989). Motivational and selfregulated learning components of classroom academic performance. Journal of Educational Psychology, 82(1), 33-40. doi:10.1037/0022-0663.82.1.33

Prieto, G., \& Muñiz, J. (2000). Un modelo para evaluar la calidad de los tests utilizados em España. Retrieved from http://www.papelesdelpsicologo.es/vernumero. asp?id=1102

Santos, A. A. A., \& Boruchovitch. E. (2001). Escala de avaliação de estratégias de aprendizagem em universitários. Unpublished manuscript.

Santos, A. A. A., \& Boruchovitch. E. (2008). Escala de avaliação de estratégias de aprendizagem em universitários. Unpublished manuscript.

Santos, A. A. A., Boruchovitch, E., Primi, R., Bueno, J. M., \& Zenorini, R. P. C. (2004). Escala de Avaliação de Estratégias de Aprendizagem para Universitários (EAP-U): Aplicação do modelo de Rasch de créditos parciais. Psicologia: Teoria, Investigação e Prática, 9(2), 227-242.

Tinajero, C., Lemos, S. M., Araújo, M., Ferraces, M. J., \& Páramo, M. F. (2012). Estilo cognitivo e estratégias de aprendizagem em estudantes universitários brasileiros: Repercussões no rendimento acadêmico. Psicologia: Reflexão e Crítica, 25(1), 105-113. doi:10.1590/S0102-79722012000100013

Wang, C., Kim, D.-K., Bong, M., \& Ahn, H. S. (2013). Korean college students' self-regulated learning strategies and self-efficacy beliefs in learning English as a foreign language. The Asian EFL Journal Quarterly, 15(3), 81-112.

Weinstein, C. E., Acee, T. W., \& Jung, J. (2011). Selfregulation and learning strategies. New Directions for Teaching and Learning, 126, 45-53. doi:10.1002/tl.443

Weinstein, C. E., \& Mayer, R. E. (1985). The teaching of learning strategies. In M. C. Wittrock (Ed.), Handbook of research on teaching (3rd ed., pp. 315-327). New York, NY: Macmillan.

Weinstein, C. E., \& Palmer, D. R. (1990). Learning and Study Strategies Inventory (LASSI). Clearwater, FL: H \& H Publishing Company.

Weinstein, C. E., Zimmerman, B. J., \& Palmer, D. R. (1988). Assessing learning strategies: The design and development of the LASSI. In E. T. Goetz \& P. A. Alexander (Eds.), Learning and study strategies. Issues in assessment, instruction and evaluation (pp. 25-40). San Diego, CA: Academic Press.

Zimmerman, B. J., \& Martinez-Pons, M. (1986). Development of a structured interview for assessing student use of self-regulated learning strategies. American Educational Research Journal, 23(4), 614-628. 
Zimmerman, B. J., \& Schunk, D. H. (2011). Handbook of self-regulation of learning and performance. New York, NY: Routledge.

Evely Boruchovitch is a Full Professor of the Faculdade de Educação of the Universidade Estadual de Campinas.

Acácia Aparecida Angeli Santos is a Full Professor of the Universidade São Francisco.

Received: Mar. 23, 2014

1st Revision: July 29, 2014

Approved: Aug. 8, 2014

How to cite this article:

Boruchovitch, E., \& Santos, A. A. A. (2015). Psychometric studies of the Learning Strategies Scale for university students. Paidéia (Ribeirão Preto), 25(60), 19-27. doi: 10.1590/1982-43272560201504 